\title{
OPEN Molecular assays to reliably detect and quantify predation on a forest pest in bats faeces
}

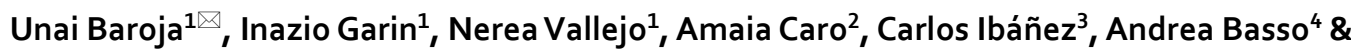 \\ Urtzi Goiti ${ }^{1}$
}

Targeted molecular methods such as conventional PCR (CPCR) and quantitative PCR (qPCR), combined with species-specific primers and probes, are widely applied for pest species detection. Besides, the potential of qPCR to quantify DNA in samples makes it an invaluable molecular tool to infer the predation levels on specific prey by analysing predators' stools. Nevertheless, studies on the diet of bats failed to find any empirical relationship, and it remains to be evaluated. Thus, we developed and evaluated two species-specific PCR assays to detect and quantify DNA of a major forest pest, the pine processionary, Thaumetopoea pityocampa, in bats' faeces. Further, we empirically compared a range of different known DNA concentrations (input) of the target species mixed with mocks and bat faecal samples against DNA abundances yielded by qPCR (output) for a quantitative assessment. Overall, CPCR showed a lower detection rate than QPCR, but augmenting the replicate effort from one to three replicates led to a greater increase in the detection rate of the CPCR (from 57 to $80 \%$ ) than the QPCR (from 90 to $99 \%$ ). The quantitative experiment results showed a highly significant correlation between the input and output DNA concentrations $(t=10.84, p<0.001)$ with a mean slope value of 1.05 , indicating the accuracy of our qPCR assay to estimate DNA abundance of $T$. pityocampa in bat faeces. The framework of this study can be taken as a model to design similar assays applicable to other species of interest, such as agricultural pests or insects of public health concern.

The pine processionary moth, Thaumetopoea pityocampa, is a significant forest pest of coniferous trees in the Western Palearctic. The larvae not only defoliate trees causing significant growth reduction and leading to severe economic losses ${ }^{1,2}$, but its urticating setae are also considered a risk to human and animal health ${ }^{3,4}$. The species is rapidly responding to climate change prolonging its active period and spreading northward ${ }^{5-7}$. Among its natural predators, insectivorous bats are common predators of adult moths ${ }^{8}$, with a vast array of bat species preying on $T$. pityocampa $a^{9}$. These bat species increase their hunting activity at pine stand edges where T. pityocampa swarms ${ }^{10}$. Some of these bat species have a broad foraging range ${ }^{11-13}$, reaching prey-abundant distant areas. During the breeding period, female bats increase their food intake imposed by pregnancy's high energetic demands ${ }^{14}$, which coincides with the high resource availability period (e.g., the outbreak of T. pityocampa). In summary, these flying mammals may precisely track the abundance of T. pityocampa and other species of interest (e.g. ${ }^{15}$ ).

Current molecular techniques for identifying bat prey in diet studies are primarily based on the metabarcoding of prey DNA in faeces (e.g. ${ }^{16-18}$ ). The high throughput sequencing of thousands of PCR amplicons in parallel renders this technique a powerful tool to study animals' diets with a high diversity of consumed taxa ${ }^{19,20}$. Nonetheless, specialised laboratory equipment and personnel are required, and the budget needed to process the data makes it impractical in many research settings. Moreover, metabarcoding brings an imbalanced amplification of the prey's DNA attributed to the differential affinity of the primer sets across taxa, which can potentially lead to false-negative results of some prey $^{21}$. Likewise, as most insectivorous bats have diverse diets, the large number of DNA sequences from multiple taxa binding to universal primers can potentially disguise the detection of some species of interes $\mathrm{t}^{20,22,23}$. In that sense, although it is tempting to assume that prey DNA sequence proportions or read counts recovered from faecal samples are representative of predator's diet proportions, digestion and amplification biases impair quantitative interpretations of the data, especially in samples containing many

\footnotetext{
${ }^{1}$ Department of Zoology and Animal Cell Biology, Faculty of Science, University of the Basque Country, UPV/EHU, Leioa, Basque Country, Spain. ${ }^{2}$ Department of Zoology and Animal Cell Biology, Faculty of Pharmacy, University of the Basque Country, UPV/EHU, Vitoria-Gasteiz, Basque Country, Spain. ${ }^{3}$ Department of Evolutionary Ecology, Estación Biológica de Doñana (CSIC), Avenida Américo Vespucio 26, 41092 Seville, Spain. ${ }^{4}$ stituto Zooprofilattico Sperimentale delle Venezie, Viale dell'Università, 10, 35020 Legnaro, Padova, Italy. ${ }^{\square}$ email: unai.baroja@ehu.eus
} 


\begin{tabular}{|c|c|c|c|c|c|c|}
\hline Primer name & Assay & Primers & Region & Sequence $5^{\prime}-3^{\prime}$ & $\operatorname{Tm}\left({ }^{\circ} \mathrm{C}\right)$ & Product (bp) \\
\hline Tpit_cF & \multirow{2}{*}{ cPCR } & ${ }_{c} \mathrm{~F}$ & \multirow{2}{*}{ TRNK-ATP8 } & TCTAATGAAACTATTAACAC & 48 & \multirow{2}{*}{131} \\
\hline Tpit_cR & & ${ }_{c} \mathrm{R}$ & & ATAATAATCAATTAATGGGC & 48 & \\
\hline Tpit_qF & \multirow{3}{*}{$\mathrm{qPCR}$} & ${ }_{\mathrm{q}} \mathrm{F}$ & \multirow{3}{*}{ ATP6 } & ATTATTCGACCCGGTACTTTGG & 62 & \multirow{3}{*}{89} \\
\hline Tpit_qR & & ${ }_{\mathrm{q}} \mathrm{R}$ & & ATAACTCTCTTAAGAAGAACAGGACC & 62 & \\
\hline Tpit_qP & & ${ }_{9} \mathrm{P}$ & & ACGATTAACAGCAAACATAATTGCCGGAC & 68 & \\
\hline
\end{tabular}

Table 1. Primer pairs and probes used in the study, the coding region, the primer sequence, the melting temperature, and the amplicon size.

$\operatorname{taxa}^{24,25}$. Consequently, reliable results of metabarcoding restrict to the qualitative assessment of the species list in the faecal samples. Hence, whereby a single-species detection is aimed, metabarcoding may fail to reliably capture the target species leading to biased results. It is therefore desirable that cheaper, targeted approaches are developed for studies which aim to detect a single species. The combination of target species-specific primers with PCR-based methods provides greater detection than metabarcoding because they only target the species of interest. Among targeted approaches, conventional PCR (cPCR) and real-time or quantitative PCR (qPCR) methods allow the amplification of minute amounts of template DNA even when the target is mixed with large amounts of non-target DNA, such as in animal scat ${ }^{26}$.

Work from several fields have succeeded in the direct detection of target species using targeted PCR methods from environmental samples, for instance, water ${ }^{27,28}$, stomach content ${ }^{26}$, predator and prey identification from its scats ${ }^{29-31}$, plant tissue ${ }^{32}$ or soil samples ${ }^{33}$. Particularly, when working with bat faeces, several factors directly influence target species' detection, primarily the mass of prey consumed and faecal collection time post-feeding, which can lead to false-negative results ${ }^{31}$. In addition, choosing the proper PCR strategy may sometimes result in a hard striking decision since both assays have their benefits and drawbacks ${ }^{34}$. Although cPCR is one of the most widespread and affordable molecular techniques, it allows amplifying a target sequence only at a qualitative level. In contrast, qPCR monitors the amplification process in real-time, and hence it provides a qualitative and quantitative assessment of the aimed sequence, but at a much higher cost. Another determining factor is the number of replicates used. Increasing PCR replicates significantly improves the detection probability by reducing the risk of false negatives and yielding more reliable results ${ }^{35}$. Making all these decisions (choosing PCR strategy or the number of replicates included) will involve a trade-off between the financial costs, logistical feasibility, and the risk of inaccurate results.

Despite the potential of qPCR to quantify DNA in samples, results obtained from these analyses have not yet shown correlations with the biomass of prey consumed by bats ${ }^{36,37}$. Indeed, several factors, such as degradation of dietary DNA during digestion or primer binding biases attributed to highly diverse prey diets, might hinder the potential of qPCR as a quantitative measure of predation.

In light of the above, the main goals of this study were to (1) develop rapid, easy and cost-effective PCR-based methods for detecting T. pityocampa in bat stools, (2) to compare the detection rates yielded by both cPCR and qPCR strategies along with different replicates and (3) to assess the accuracy of qPCR as a tool for estimating the abundance of T. pityocampa consumed by insectivorous bats.

\section{Material and methods}

Primer design. For CPCR, we designed specific primer sets to T. pityocampa from the $3^{\prime}$ end of TRNK to the $5^{\prime}$ of ATP8 regions of the mitochondrial DNA using PerlPrimer software (Ref. ${ }^{38}$, see Table 1). For that, we first downloaded all the available sequences from their congeneric species (Thaumetopoea spp., see Ref. ${ }^{39}$ ) on GenBank (www.ncbi.nlm.nih.gov/genbank/2) and BOLD (www.boldsystems.org). Then we aligned them using MAFFT $^{40}$, and we identified binding sites. Finally, we verified primers' specificity in silico against available sequence data in the GenBank nucleotide database (https://www.ncbi.nlm.nih.gov/genbank/). For qPCR, we designed T. pityocampa specific primers and Taq-man probes optimised for qPCR reactions using the PrimerQuest Design Tool (Integrated DNA Technologies, https://eu.idtdna.com/) for the amplification of mitochondrial gene ATP6 (Table 1) with the following custom parameters:

- Primers melting temperature $(\mathrm{Tm})$ of $62^{\circ} \mathrm{C}$, GC content of $50 \%$, and 22 bp length.

- Probe Tm of $68^{\circ} \mathrm{C}$, GC content of $50 \%$, and 24 bp length.

The specificity of the assemblage of primers and probes suggested by the software was checked and verified in silico against available sequence data (https://www.ncbi.nlm.nih.gov/genbank/). We selected the primers, probe and amplicon sequences specific to T. pityocampa (100\% similarity value, Table 1$)$.

DNA sampling. Primers were empirically tested in both fresh T. pityocampa samples and bat faecal samples to test their efficiency by both PCR techniques.

Fresh T. pityocampa male moths were collected from the Basque Country (Southwestern Europe) using pheromone-baited G-traps (Econex, Murcia, Spain). Traps were suspended from trees at the height of $\sim 4 \mathrm{~m}$. Additionally, we placed a couple of light traps during a single night to capture moths other than T. pityocampa. 
Insects were then collected and stored at $-80^{\circ} \mathrm{C}$ until processed. A couple of hind legs from individuals of $T$. pityocampa and other moth species were used for DNA extraction (Table S1). The whole extraction process was carried out according to the protocol described by Ref. ${ }^{41}$ with slight modifications. In fact, after washing the DNA pellets with $70 \%$ ethanol, we centrifuged them for $10 \mathrm{~min}, 4^{\circ} \mathrm{C}$ at $13,000 \mathrm{rpm}$, dried them at $60{ }^{\circ} \mathrm{C}$ for $30 \mathrm{~min}$ and resuspended them in $30 \mu \mathrm{L} \mathrm{ddH}_{2} 0$ overnight. Likewise, we collected bat droppings in 2014, 2016, 2017 and 2018 underneath bat colony clusters of different species (Myotis crypticus, M. daubentonii, M. emarginatus, Miniopterus schreibersii, Pipistrellus kuhlii, P. pipistrellus, Rhinolophus euryale, R. hipposideros, R. ferrumequinum-M. emarginatus and Tadarida teniotis) throughout different Iberian Peninsula regions (Basque Country and Andalusia, Fig. S1). Stools were then dried at $40{ }^{\circ} \mathrm{C}$ and stored at $-80^{\circ} \mathrm{C}$ until processed. No animal ethics clearance was required for this study because samples were passively and noninvasively collected underneath bat colony clusters, not involving manipulation of endangered or legally protected species.

DNA from these faecal samples was extracted as explained in Ref. ${ }^{17}$, and extraction products were stored at $-20^{\circ} \mathrm{C}$. We included an extraction control with each round. An aliquot from these DNA extracts was further analysed through metabarcoding according to the protocol described by Ref. ${ }^{15}$. The aforementioned samples were classified as follows (for further information, see Table S1):

1. C+, DNA samples from fresh T. pityocampa (positive controls),

2. C-, DNA samples from fresh moths other than T. pityocampa (negative controls),

3. Th+, DNA samples from bat faeces containing traces of T. pityocampa according to metabarcoding (sequences matching $98.5 \%$ similarity value ${ }^{42}$ exclusively with $T$. pityocampa were considered),

4. Th-, DNA samples from bat faeces in which traces of the pest were not found.

Similarly, we aimed to evaluate whether the developed PCR assays are more sensitive than metabarcoding at detecting T. pityocampa. Thus, we divided Th-samples into two subgroups:

4.1 $\mathrm{Th}_{\text {out }}{ }^{-}$, samples collected in non-forest habitats and out of the T. pityocampa flight period,

4.2 $\mathrm{Th}_{\text {in }}{ }^{-}$, samples collected within forest habitats throughout the T. pityocampa flight period.

CPCR and qPCR. In the qPCR framework, A260/280 ratio is routinely used for purity assessment of DNA, which is an indication of its presence and quality ${ }^{43}$. Impure samples have ratios outside an acceptable range and they are therefore discarded from the analysis. Thus, in all, we selected 184 samples for analysis $(C+, \mathrm{n}=6$; $C-, \mathrm{n}=18 ; T h+=96 ; T h-=63$ ), but only the samples meeting some purity criteria were retained (A260/A280 ratio $1.77 \pm 0.24 ; \mathrm{n}=169$ ). We only kept quantification data from $\mathrm{qPCR}$ runs with $\mathrm{R}^{2}$ values of $\geq 0.98$ and slopes between 3.19 and 3.71, which indicated $86-105 \%$ efficiency of qPCR reactions.

Qualitative assessment. To validate the detection efficiency of both PCR techniques, the size of each sample group was as follows (Table S1):

- C+: 5 samples;

- $C-: 7$ samples;

- Th+: 83 samples;

- $T h_{\text {out }}-: 22$ samples);

- $T h_{\text {in }}-: 21$ samples).

We assayed each sample in triplicate, and we included a negative PCR with each round. For cPCR, we compared several PCR protocols and master mixes in an initial pilot study, and finally, we selected the KAPA HiFi HotStart ReadyMix PCR Kit, which performed best. The amplifications were conducted in $25 \mu \mathrm{L}$ containing 12.5 $\mu \mathrm{L}$ KAPA HiFi ReadyMix, $1.25 \mu \mathrm{L}$ of each primer $(10 \mu \mathrm{M}), 9 \mu \mathrm{L}$ Milli-Q $\mathrm{H}_{2} \mathrm{O}$ and $1 \mu \mathrm{L}$ of template DNA per sample. The reaction conditions included: $95^{\circ} \mathrm{C}$ for $3 \mathrm{~min}$, followed by $10 \mathrm{cycles}$ of $95^{\circ} \mathrm{C}$ for $30 \mathrm{~s}, 50^{\circ} \mathrm{C}\left(-0.5^{\circ} \mathrm{C} /\right.$ cycle ramp) for $30 \mathrm{~s}$ and $72{ }^{\circ} \mathrm{C}$ for $30 \mathrm{~s}, 25$ cycles of $95^{\circ} \mathrm{C}$ for $30 \mathrm{~s}, 48{ }^{\circ} \mathrm{C}$ for $30 \mathrm{~s}, 72{ }^{\circ} \mathrm{C}$ for $30 \mathrm{~s}$ and ended by $72^{\circ} \mathrm{C}$ for $10 \mathrm{~min}$. PCR products were migrated with a DNA $5 \mathrm{~K}$ Reagent kit in a LabChip GX Touch 24 Nucleic Acid Analyzer. For qPCR, before amplification processing, we quantified DNA from each sample by a NanoDrop 8000 and based on this quantification, we adjusted the DNA concentration to $10 \mathrm{ng} / \mu \mathrm{L}$. Afterward, qPCR reactions were performed in a CFX96 Touch Real-Time PCR system (Bio-Rad) using $5 \mu \mathrm{L}$ NZY qPCR Probe Master Mix $(2 \mathrm{x})$ mixture, $0.4 \mu \mathrm{L}$ of each primer $(10 \mathrm{mM}), 0.1 \mu \mathrm{L}$ of probe $(10 \mathrm{mM}), 3.1 \mu \mathrm{L}$ nuclease-free $\mathrm{H}_{2} \mathrm{O}$ and $1 \mu \mathrm{L}$ template DNA for a total volume of $10 \mu \mathrm{L}$. The amplification conditions were: $95^{\circ} \mathrm{C}$ for $10 \mathrm{~min}$, followed by 40 cycles of $95^{\circ} \mathrm{C}$ for $15 \mathrm{~s}$ and $62^{\circ} \mathrm{C}$ for $45 \mathrm{~s}$. In order to test primers' specificity, some PCR products (cPCR, n = 5; $\mathrm{qPCR}, \mathrm{n}=7$ ) were purified and sequenced in forward and reverse directions using either an ABI3730XL or an ABI3700 Genetic Analyser (Applied Biosystems). The resulting forward and reverse sequences were assembled using BioEdit 7.1 $1^{44}$ or Geneious 8.0.2 $2^{45}$ and checked for errors and ambiguities.

Quantitative assessment. We assessed qPCR's quantification accuracy in two types of media: moths mocks and bat faecal samples (Table S2). We prepared mock mixtures composed of DNA from combinations of seven common prey species of bats (Lobesia botrana and Cydia funebrana [Tortricidae], Synthymia fixa, Catocala nymphagoga, Lymantria dispar, Noctua pronuba, Eremobia ochroleuca [Noctuidae]) with equal amounts of DNA. We also incorporated some of the faecal samples collected in non-forest habitats in which DNA traces of $T$. pityocampa were not found by metabarcoding $\left(T_{h_{\text {out }}}{ }^{-}\right)$belonging to different bat species (i.e., Rhinolophus hippo- 


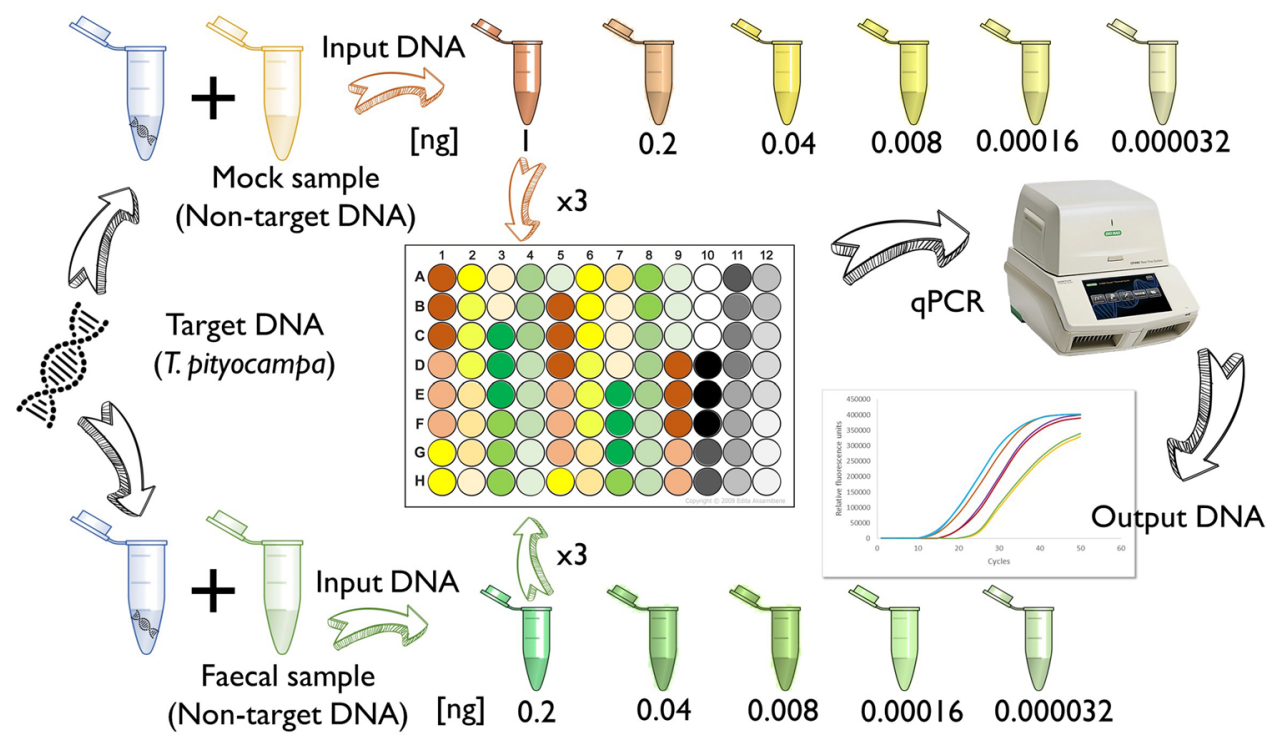

Figure 1. Overview of the experimental workflow for the quantitative assessment of qPCR.

sideros, Pipistrellus pipistrellus, P. kuhlii, Myotis daubentonii, Fig. S1), to include DNA of a broader range of prey associated with the particular feeding habits of each bat species. DNA of samples was quantified by a NanoDrop 8000 , and subsequently, it was diluted to adjust DNA concentrations to specific gradients (assays with 1, 0.2, $0.04,0.008,0.00016$ and $0.000032 \mathrm{ng} / \mu \mathrm{L}$ DNA, Fig. 1). Finally, we empirically compared known concentrations of target DNA (hereafter called "input DNA") and estimated concentrations by qPCR (hereafter called "output DNA").

For the experiment, we tested (1) 29 mock sample mixtures, i.e., fresh DNA from T. pityocampa $(C+)$ mixed with DNA of other moths $(C-)$ and (2) 35 faecal sample mixtures, mixed DNA from fresh T. pityocampa $(C+)$ and bat faeces without $T$. pityocampa $\left(T_{\text {out }^{-}}\right.$) (Fig. 1). In faecal mixtures, T. pityocampa DNA concentration of $1 \mathrm{ng} / \mu \mathrm{L}$ was not used due to problems in maintaining molarity values. The amplification process was carried out following the same qPCR protocol described above. Besides, we also constructed standard curves in triplicate using a five-fold dilution series of targeted templates, from $3.3 \times 10^{6}$ to $5.2 \times 10^{10}$ copies per $\mu \mathrm{L}$, to predict the abundance of target DNA present in tested samples.

Data analysis. All the statistical analyses were carried out in R Studio v. 1.4.1103 and R v.4.0.3. ${ }^{46}$. We conducted further analysis for each of the following questions:

The effect of replication effort on detection probabilities. As described by Ref. ${ }^{27}$, an increase in the PCR replication effort leads to an increased likelihood of detecting a target present in the sample. Accordingly, we aimed to evaluate the detection probabilities over the three replicates, for which we used the following equation for each of the replicates:

$$
\mathrm{D} /(\mathrm{D}+\mathrm{ND}) \text {, }
$$

where $\mathrm{D}$ is the number of detections and ND is the number of non-detections.

The relationship between DNA quantity and detection probability by $c P C R$ and $q P C R$. We should expect a higher detection rate in those samples with a higher target DNA concentration. Hence, we examined if there is a relationship between the average DNA abundance estimated from triplicates of $T h+$ samples by qPCR and the detection rates by each PCR assay over the three replicates, for which we fitted logistic regression models (quasibinomial family) using $g l m$ function of the stats package in $\mathrm{R}^{46}$.

The relationship between input and output DNA concentrations. We tested whether the input DNA concentrations correlated with the average concentrations estimated by triplicated samples in both mock and faecal samples and determined our qPCR technique's accuracy to predict target DNA concentrations. For that, we compared abundances yielded by qPCR against the expected DNA concentrations. Ideally, we should expect a positive correlation with a slope near 1 . Hence, we initially fitted a linear regression model, but the residual spread increased along with the explanatory variable, which violated the homogeneity of variance assumption of our linear regressions. Therefore, we fitted a generalised least squares (GLS) model with a combined variance structure using the varComb function of the $n l m e$ package ${ }^{47}$, allowing an increase in the residual spread for larger input DNA concentrations as well as a different spread per sample type (mock or faecal). Afterwards, we carried out a likelihood ratio test for the fixed component selection, comparing nested models with three possible 


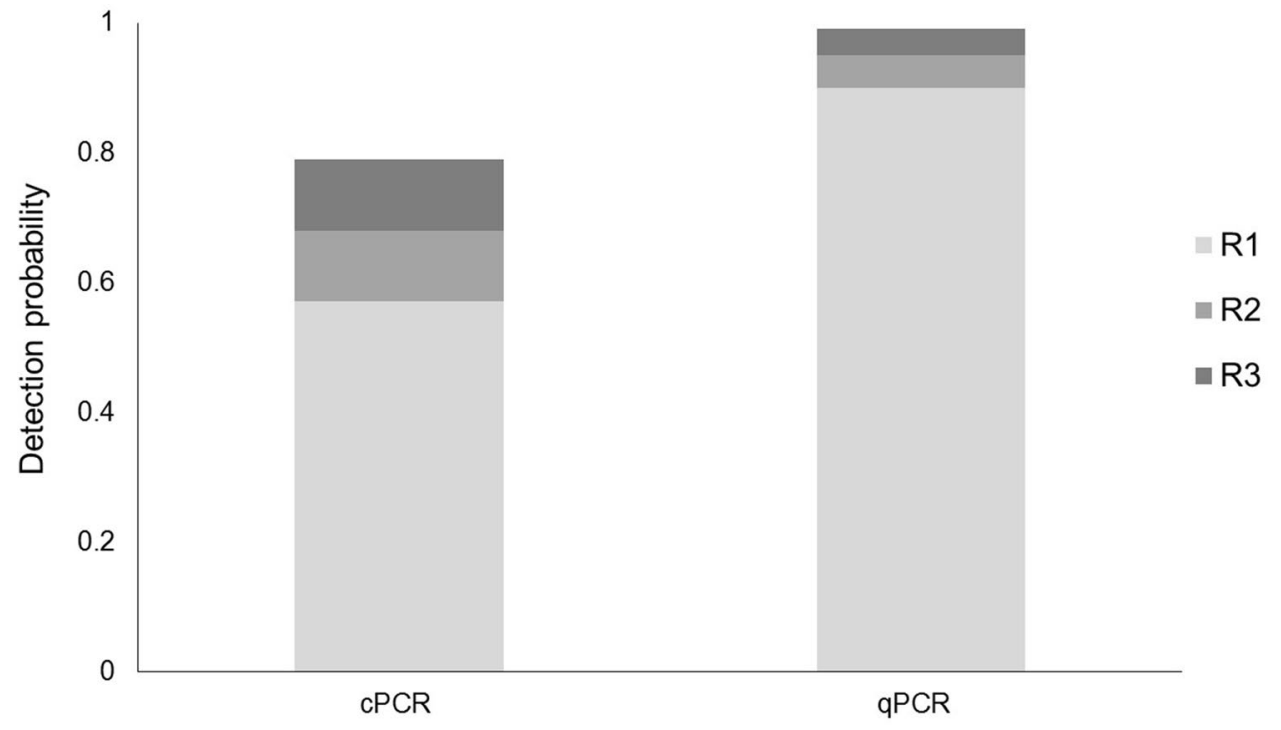

Figure 2. Detection probability of T. pityocampa DNA traces in faecal samples for each PCR assay as we increased the replicate effort (R).

explanatory variables: run, sample type and input DNA. The test indicated that neither run nor sample type were important variables affecting the yielded DNA by qPCR. Therefore, the final model only included input DNA as an explanatory variable. We plotted all the models using the ggplot2 package ${ }^{48}$.

\section{Results}

Sequence analysis of the qPCR products revealed that all the T. pityocampa amplicons were $100 \%$ identical to the expected $89 \mathrm{bp}$ fragment (Fig. S2). cPCR products also exclusively matched to T. pityocampa, but they did not show the same consistency as qPCR. Indeed, only two reverse sequences from CPCR sequencing analysis were $99 \%$ and $95 \%$ similar to the 131 bp fragment sequence, respectively. The rest of the sequences were not long enough to assess the adscription of the fragment.

Overall, none of the negative controls showed signs of amplification and all the positive controls and their corresponding replicates exhibited amplification signals in both PCR assays (Fig. S3, Table S1). cPCR showed a lower detection rate than qPCR for $T h+$ samples (Fig. 2), besides the increasing number of test replicates had a bigger impact on the detectability rate of the CPCR than the qPCR. Both assays tested negative for $T h_{\text {out }}-$ samples, $_{\text {, }}$ but some $T h_{i n}$-samples resulted in positive DNA signals (Table S1). Further, some samples tested with cPCR showed some nonspecific bands of different DNA fragment lengths together with the targeted band (Table S1).

Higher DNA concentrations of T. pityocampa in $T h+$ samples resulted in an increased detection probability by the $\mathrm{qPCR}(\mathrm{t}=2.21, \mathrm{p}<0.05)$, whereas that correlation did not hold for the $\mathrm{cPCR}$ assay $(\mathrm{t}=1.16, \mathrm{p}=0.25)$ (Fig. 3).

The results from the quantitative assessment experiment showed there is a highly significant correlation between the input and output DNA concentrations $(t=10.84, p<0.001)$ with a mean slope value of $1.05(95 \%$ CI 0.85 to 1.23 ) (Fig. 4). This output indicated that the average DNA concentration estimated from qPCR triplicates represented the DNA concentration present in the sample within a range of $85 \%$ and $123 \%$.

\section{Discussion}

We observed that the performance of two primer sets and PCR methods differed, affecting their efficiency to detect DNA traces of T. pityocampa in bat faeces. Studies on predator-prey trophic interactions are currently among the main highlights of ecological research (e.g. ${ }^{42,49-51}$ ). In this context, finding robust molecular methods to reliably identify and quantify DNA of prey remains in predators' faeces is a fundamental issue, for instance, to gain insight into the ecosystem services provided by predators as pest suppressors.

Both PCR assays exclusively identified T. pityocampa, as revealed by the sequencing analysis, indicating they are highly specific to our target. In some samples, though, cPCR produced a predominant target band of $131 \mathrm{bp}$ with multiple nonspecific bands of different DNA fragment length, which suggests a reduction in the efficiency of the amplification, likely due to non-optimal amplification conditions, such as sub-optimal annealing temperatures ${ }^{52}, \mathrm{MgCl} 2$ concentration, primer concentration, or PCR cycling conditions ${ }^{53}$.

Comparison of cPCR and qPCR. In line with previous findings of ${ }^{27,54,55}, \mathrm{qPCR}$ had a higher sensitivity than CPCR. It proved to be a more reliable and robust assay to detect T. pityocampa in bat faecal samples for two main reasons.

Replication effort. Increasing the number of replicates leads to an improvement in the DNA detection probability. Nonetheless, while cPCR requires up to three replicates to detect T. pityocampa in the $80 \%$ of $T h+$ samples, 


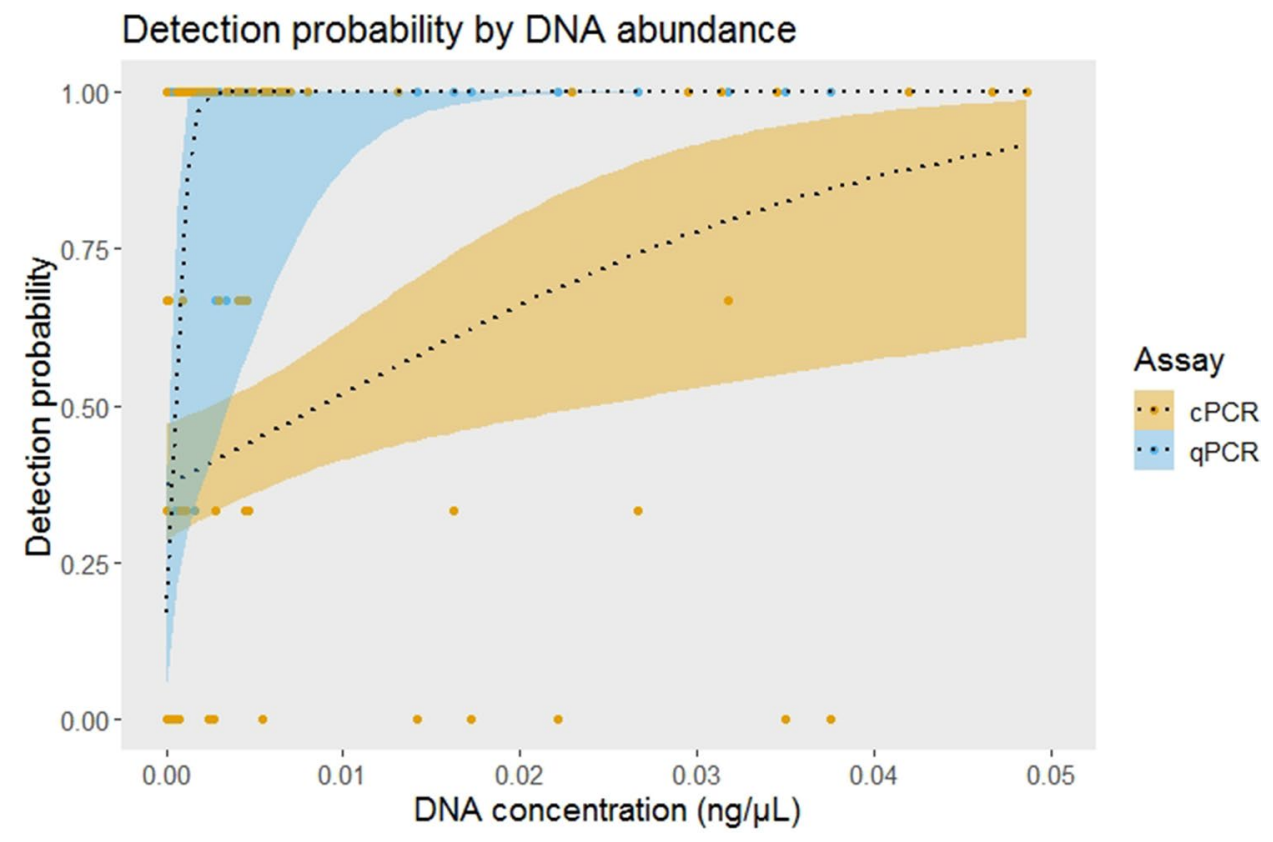

Figure 3. The relationship between the detection probability and DNA concentration for $\mathrm{CPCR}$ and $\mathrm{qPCR}$. The dotted lines indicate the fitted regression model and the coloured bands the $95 \%$ confidence interval.

\section{Quantification assessment}

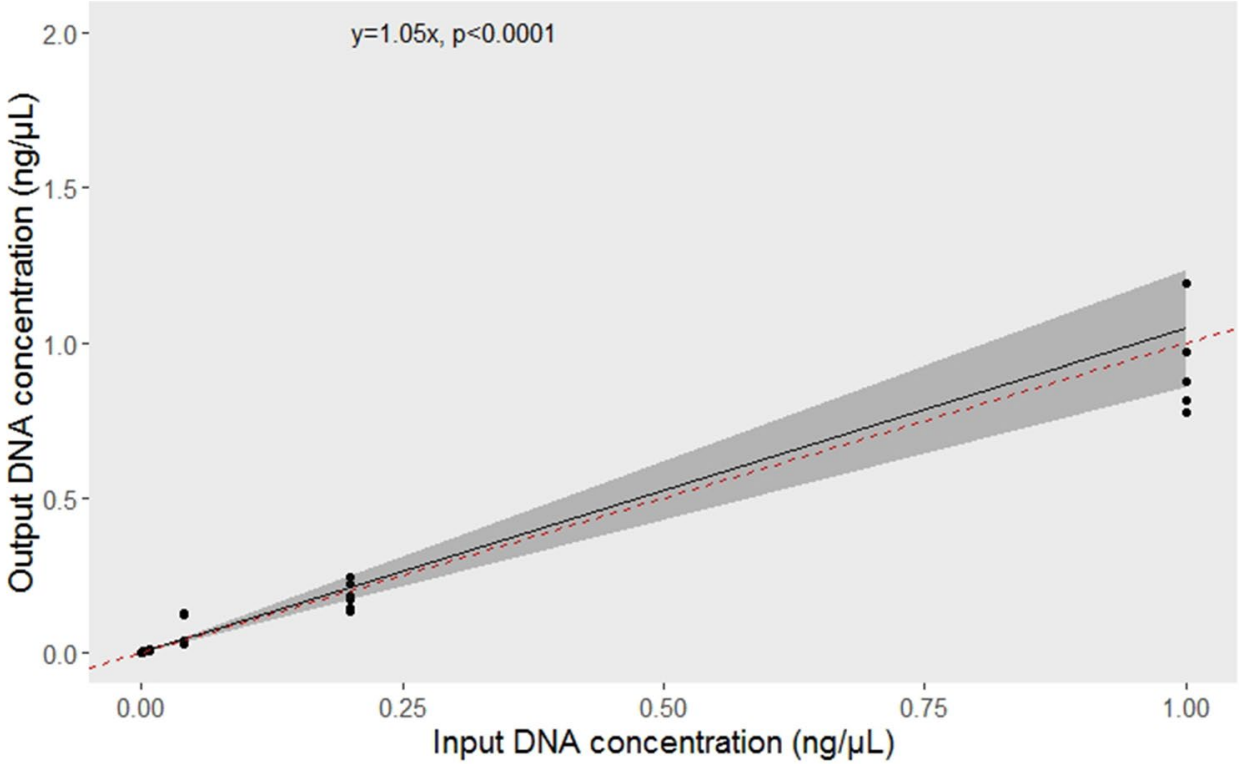

Figure 4. The relationship between the input and output DNA concentration. The grey band indicates the $95 \%$ confidence interval and the dotted red line represents a slope of 1.

qPCR detected the target in $90 \%$ of the samples with a single replicate and $99 \%$ of them with three replicates. The only sample not tested positive by any of the PCR assays was processed in 2014, and only 8 copies of the target sequence were found that time by metabarcoding. Hence, we cannot discard that the DNA degradation in such an old sample might have hampered the detection of T. pityocampa.

Detectability and DNA concentration. Ideally, a robust PCR method for species monitoring should reliably detect the target species, increasing the detection probability as the target DNA concentration in the sample rises $^{56}$. In line with this, the qPCR assay results showed a positive relationship between DNA concentration and 


\begin{tabular}{|c|c|c|c|c|}
\hline Technique & Advantages & Limitations & Usage & Costs \\
\hline Metabarcoding & $\begin{array}{l}\text { Wide dietary breadth. No need for a priori } \\
\text { knowledge of the diet } \\
\text { Multiple samples per run }(\approx 384) \\
\text { Universal primers that are usually prede- } \\
\text { signed }\end{array}$ & $\begin{array}{l}\text { Less sensitive than qPCR for single species } \\
\text { detection } \\
\text { Target organisms must be in the reference } \\
\text { databases } \\
\text { Expensive equipment and reagents } \\
\text { High workload (library preparation, } \\
\text { sequencing, bioinformatics) }\end{array}$ & $\begin{array}{l}\text { Diverse diet studies } \\
\text { Complex trophic networks }\end{array}$ & $5.30-8.60 € /$ replicate \\
\hline cPCR & $\begin{array}{l}\text { Specific } \\
\text { Low-cost (equipment and reagents) }\end{array}$ & $\begin{array}{l}\text { Post-PCR (time consuming, possible cross- } \\
\text { contamination) } \\
\text { Low sensitivity } \\
\text { Three replicates, at least } \\
\text { Qualitative assay (presence-absence) } \\
\text { Specific primers for a target pest may not } \\
\text { always be possible }\end{array}$ & $\begin{array}{l}\text { Pilot studies: primary step to evaluate the } \\
\text { interest of any further analysis } \\
\text { Overall screening at a low price }\end{array}$ & $0.17 € /$ replicate \\
\hline qPCR & $\begin{array}{l}\text { Highly specific and sensitive } \\
\text { Rapid analysis (No post-PCR) } \\
\text { Qualitative and quantitative assay } \\
\text { Multiple samples per run }(\approx 120 \text { in a } 384 \text {-well } \\
\text { plate with three replicates) }\end{array}$ & $\begin{array}{l}\text { High costs (equipment and reagents) } \\
\text { Specific primer and probes for a target pest } \\
\text { may not always be possible }\end{array}$ & $\begin{array}{l}\text { Relative levels of predation on particular } \\
\text { prey species }\end{array}$ & $1.50 € /$ replicate \\
\hline
\end{tabular}

Table 2. Advantages, limitations, usage and costs of the molecular techniques used in the study.

the detection probability, which suggests that a higher incidence of T. pityocampa in bats' diet entails a greater likelihood of detection. In contrast, the lack of such correlation in CPCR denotes that the detectability of T. pityocampa might be influenced by other disturbing factors, such as the presence of PCR inhibitors in some samples. In fact, they affect more severely to CPCR than qPCR owing to its less sensitive detection mechanisms ${ }^{54,57}$, which in turn, prompt false-negative results ${ }^{58}$, and a higher unpredictability.

Diet quantification by qPCR. Our study also demonstrates the potential of qPCR assays to quantify DNA in bat faecal samples and, as a result, infer the predation levels on specific prey. We undertook extensive validation steps using mocks and faecal samples from a vast array of bat species, suggesting that the developed qPCR assay is robust for quantifying T. pityocampa in the bat faeces irrespective of the sample source. Further methodological studies should focus on developing or improving current molecular tools for the simultaneous identification and quantification of highly diverse polyphagous predators' diets, where dozens of species occur at a time (e.g. $\left.{ }^{17}\right)$. The framework of this study can be taken as a model to design similar assays applicable to other species of interest, such as agricultural pests or insects of public health concern. Further, the incorporation of the multiplex qPCR, including Taq-man probes with various dyes, will enable the simultaneous amplification of multiple prey targets in a single reaction (Ref. ${ }^{59}$; e.g., up to five species with the CFX96 Real-Time PCR Detection System used in the study). Because of the affinity differences between primers and their target sequences ${ }^{28}$, quantitative interpretations from dietary data must focus on the intraspecific variations between samples rather than on interspecific differences.

Decision making. Currently, the two most common approaches to detect DNA from environmental samples rely typically on using metabarcoding with Next Generation Sequencing (NGS) for the simultaneous identification of multiple taxa or on using targeted PCR approaches through species-specific primers and probes. Deciding on which one to use depends on the research question and available economic and personnel resources. The advantages, limitations and usage of each technique are further discussed (Table 2).

Metabarcoding. Metabarcoding allows the parallel processing and sequencing of several hundred samples per run ${ }^{60}$. Thus, in the last decade, metabarcoding has emerged as an invaluable molecular tool for characterising diet breadth in polyphagous predators. It offers unique opportunities for deciphering trophic interactions within food webs ${ }^{61}$. Nonetheless, this gain in trophic network understanding comes at the cost of accuracy and sensitivity for target species detection ${ }^{62}$. For instance, the results of our study revealed that more than $10 \%$ of the samples which returned no metabarcoding reads that were assigned to T. pityocampa, contain the species when using cPCR or qPCR (Table S1). Therefore, if a study requires information on a species-rich or unknown diet, metabarcoding is likely the appropriate technique. However, targeted approaches can be superior if there are specific prey items of interest, quantification of these prey is desired, or rapid and cost-effective analyses are required.

CPCR. The results from the CPCR revealed that the assay is $80 \%$ effective as long as three replicates per sample are used. Further, augmenting the replication effort may lead to an increase in the detection rate of T. pityocampa, as shown in Fig. 2. The technique can be beneficial for pilot studies, for instance, as a primary step to evaluate the interest of any further analysis, or even for timely detection of T. pityocampa in bat faeces before pest population settlement ${ }^{63}$, which offer valuable information for pest management to avoid further irreparable damage to the pine stands. In addition, one of the main advantages of this assay lies in its low price (e.g., 0.17€/ replicate $\left.{ }^{64}\right)$ compared with qPCR $\left(1.50 € /\right.$ replicate $\left.^{64}\right)$ or metabarcoding $\left(5.30-8.60 € /\right.$ replicate $\left.{ }^{65}\right)$, which makes it affordable for almost any research study. However, we do not recommend the assay for exhaustive monitoring in studies requiring high sensitivity. 
qPCR. The qPCR assay offers a fined-grained qualitative and quantitative assessment of T. pityocampa in bats' diet. As such, the approach has a dual-use as it can be used for both presence-absence monitoring and as an approximation of T. pityocampa biomass consumed by bats. In addition, a single replicate produces still a $90 \%$ detection rate and consequently, costs per sample may be reduced. For quantification purposes though, there is considerable variability between replicates and we must keep at least three replicates per sample to ensure the reliability of the quantitative assessment.

\section{Data availability}

All the data are available in the manuscript or Supplementary Material.

Received: 7 August 2021; Accepted: 25 January 2022

Published online: 10 February 2022

\section{References}

1. Buxton, R. D. Forest management and the pine processionary moth. Outlook Agric. 12, 34-39 (1983).

2. Gatto, P. et al. Economic assessment of managing processionary moth in pine forests: A case-study in Portugal. J. Environ. Manage. 90, 683-691 (2009).

3. Battisti, A., Larsson, S. \& Roques, A. Processionary moths and associated urtication risk: Global change-driven effects. Annu. Rev. Entomol. 62, 323-342 (2017).

4. Moneo, I. et al. Medical and veterinary impact of the urticating processionary larvae. In Processionary Moths and Climate Change: An Update, 359-410 (Springer, 2015).

5. Battisti, A. et al. Expansion of geographic range in the pine processionary moth caused by increased winter temperatures. Ecol. Appl. 15, 2084-2096 (2005).

6. Kerdelhué, C. et al. Quaternary history and contemporary patterns in a currently expanding species. BMC Evol. Biol. 9, 220 (2009).

7. Robinet, C., Rousselet, J., Pineau, P., Miard, F. \& Roques, A. Are heat waves susceptible to mitigate the expansion of a species progressing with global warming?. Ecol. Evol. 3, 2947-2957 (2013).

8. Auger-Rozenberg, M. A. et al. Ecological responses of parasitoids, predators and associated insect communities to the climatedriven expansion of the pine processionary moth. In Processionary Moths and Climate Change: An Update, 311-357 (Springer, 2015).

9. Garin, I. et al. Bats from different foraging guilds prey upon the pine processionary moth. PeerJ 7, e7169 (2019).

10. Charbonnier, Y., Barbaro, L., Theillout, A. \& Jactel, H. Numerical and functional responses of forest bats to a major insect pest in pine plantations. PLoS ONE 9, e109488 (2014).

11. Goiti, U., Aihartza, J. R., Almenar, D., Salsamendi, E. \& Garin, I. Seasonal foraging by Rhinolophus euryale (Rhinolophidae) in an Atlantic rural landscape in northern Iberian Peninsula. Acta Chiropterol. 8, 141-155 (2006).

12. Russo, D. et al. Habitat selection in sympatric Rhinolophus mehelyi and R. euryale (Mammalia: Chiroptera). J. Zool. 266, 327-332 (2005).

13. Vincent, S., Nemoz, M. \& Aulagnier, S. Activity and foraging habitats of Miniopterus schreibersii (Chiroptera: Miniopteridae) in southern France: Implications for its conservation. Hystrix Ital. J. Mammal. https://doi.org/10.4404/hystrix-22.1-4524 (2010).

14. Rydell, J. Site fidelity in the northern bat (Eptesicus nilssoni) during pregnancy and lactation. J. Mammal. 70, 614-617 (1989).

15. Baroja, U. et al. Bats actively track and prey on grape pest populations. Ecol. Indic. 126, 107718 (2021).

16. Aldasoro, M. et al. Gaining ecological insight on dietary allocation among horseshoe bats through molecular primer combination. PLoS ONE 14, e0220081 (2019).

17. Baroja, U. et al. Pest consumption in a vineyard system by the lesser horseshoe bat (Rhinolophus hipposideros). PLoS ONE 14, e0219265 (2019)

18. Vallejo, N. et al. The diet of the notch-eared bat (Myotis emarginatus) across the Iberian Peninsula analysed by amplicon metabarcoding. Hystrix Ital. J. Mammal. 30, 59-64 (2019).

19. Bohmann, K. et al. Molecular diet analysis of two African free-tailed bats (Molossidae) using high throughput sequencing. PLoS ONE 6, e21441 (2011).

20. Pompanon, F. et al. Who is eating what: Diet assessment using next generation sequencing?. Mol. Ecol. 21, 1931-1950 (2012).

21. Elbrecht, V. \& Leese, F. Validation and development of COI metabarcoding primers for freshwater macroinvertebrate bioassessment. Front. Environ. Sci. 5, 11 (2017).

22. Evans, N. T. et al. Quantification of mesocosm fish and amphibian species diversity via environmental DNA metabarcoding. Mol. Ecol. Resour. 16, 29-41 (2016).

23. Harper, L. R. et al. Needle in a haystack? A comparison of eDNA metabarcoding and targeted qPCR for detection of the great crested newt (Triturus cristatus). Ecol. Evol. 8, 6330-6341 (2018).

24. Deagle, B. E. et al. Counting with DNA in metabarcoding studies: How should we convert sequence reads to dietary data?. Mol. Ecol. 28(2), 391-406 (2019).

25. Piñol, J., Mir, G., Gomez-Polo, P. \& Agustí, N. Universal and blocking primer mismatches limit the use of high-throughput DNA sequencing for the quantitative metabarcoding of arthropods. Mol. Ecol. Resour. 15, 819-830 (2015).

26. Jarman, S. N., Deagle, B. E. \& Gales, N. J. Group-specific polymerase chain reaction for DNA-based analysis of species diversity and identity in dietary samples. Mol. Ecol. 13, 1313-1322 (2004).

27. Piggott, M. P. Evaluating the effects of laboratory protocols on eDNA detection probability for an endangered freshwater fish. Ecol. Evol. 6, 2739-2750 (2016).

28. Knudsen, S. W. et al. Species-specific detection and quantification of environmental DNA from marine fishes in the Baltic Sea. J. Exp. Mar. Biol. Ecol. 510, 31-45 (2019).

29. Kaňuch, P., Hájková, P., Řehák, Z. \& Bryja, J. A rapid PCR-based test for species identification of two cryptic bats Pipistrellus pipistrellus and P. pygmaeus and its application on museum and dropping samples. Acta Chiropterol. 9, 277-282 (2007).

30. Czernik, M. et al. Fast and efficient DNA-based method for winter diet analysis from stools of three cervids: Moose, red deer, and roe deer. Acta Theriol. 58, 379-386 (2013).

31. Schattanek, P., Riccabona, S. A., Rennstam Rubbmark, O. \& Traugott, M. Detection of prey DNA in bat feces: Effects of time since feeding, meal size, and prey identity. Environ. DNA 3, 959-969 (2021).

32. Martin, K. J. \& Rygiewicz, P. T. Fungal-specific PCR primers developed for analysis of the ITS region of environmental DNA extracts. BMC Microbiol. 5, 28 (2005).

33. Nowakowska, J. A., Malewski, T., Tereba, A. \& Oszako, T. Rapid diagnosis of pathogenic Phytophthora species in soil by real-time PCR. For. Pathol. 47, e12303 (2017).

34. Bott, N. J. et al. Toward routine, DNA-based detection methods for marine pests. Biotechnol. Adv. 28, 706-714 (2010).

35. Schmidt, B. R., Kery, M., Ursenbacher, S., Hyman, O. J. \& Collins, J. P. Site occupancy models in the analysis of environmental DNA presence/absence surveys: A case study of an emerging amphibian pathogen. Methods Ecol. Evol. 4, 646-653 (2013). 
36. McCracken, G. F., Brown, V. A., Eldridge, M. \& Westbrook, J. K. The use of fecal DNA to verify and quantify the consumption of agricultural pests. Bat Res. News 46, 195-196 (2005).

37. McCracken, G. F. et al. Bats track and exploit changes in insect pest populations. PLoS ONE 7, e43839 (2012).

38. Marshall, O. J. PerlPrimer: Cross-platform, graphical primer design for standard, bisulphite and real-time PCR. Bioinformatics 20, 2471-2472 (2004).

39. Simonato, M. et al. Host and phenology shifts in the evolution of the social moth genus Thaumetopoea. PLoS ONE 8, e57192 (2013).

40. Katoh, K. \& Standley, D. M. MAFFT multiple sequence alignment software version 7: Improvements in performance and usability. Mol. Biol. Evol. 30, 772-780 (2013).

41. Aljanabi, S. M. \& Martinez, I. Universal and rapid salt-extraction of high quality genomic DNA for PCR-based techniques. Nucleic Acids Res. 25, 4692-4693 (1997).

42. Razgour, O. et al. High-throughput sequencing offers insight into mechanisms of resource partitioning in cryptic bat species. Ecol. Evol. 1, 556-570 (2011).

43. Page, A. \& Gomez-Curet, I. Assuring reliability of qPCR \& RT-PCR results: Use of spectrophotometry on nucleic acid samples before experiment improves outcome. Genet. Eng. Biotechnol. News 31(16), 26-26 (2011).

44. Hall, T. A. ioEdit: A user-friendly biological sequence alignment editor and analysis program for Windows 95/98/NT. Nucleic Acids Symp. Ser. 41, 41 (1999).

45. Kearse, M. et al. Geneious basic: An integrated and extendable desktop software platform for the organisation and analysis of sequence data. Bioinformatics 28, 1647-1649 (2012).

46. R Core Team. R: A Language and Environment for Statistical Computing (2020). (R Foundation for Statistical Computing). https:// www.R-project.org/. Accessed 10 May 2021.

47. Pinheiro, J., Bates, D., DebRoy, S. \& Sarkar, D. nlme: Linear and nonlinear mixed effects models. R Package Version 3, 1-89 (2021).

48. Wickham, H. Ggplot2: Elegrant Graphics for Data Analysis (Springer, 2016).

49. Arrizabalaga-Escudero, A. et al. Trait-based functional dietary analysis provides a better insight into the foraging ecology of bats. J. Anim. Ecol. 88, 1587-1600 (2019).

50. Curtsdotter, A. et al. Ecosystem function in predator-prey food webs-Confronting dynamic models with empirical data. J. Anim. Ecol. 88, 196-210 (2019).

51. Michalko, R., Pekár, S. \& Entling, M. H. An updated perspective on spiders as generalist predators in biological control. Oecologia 189, 21-36 (2019).

52. Sun, C. et al. polymerase chain reaction assisted by metal-organic frameworks. Chem. Sci. 11, 797-802 (2020).

53. Roux, K. H. Optimisation and troubleshooting in PCR. Cold Spring Harbor Protoc. 4, 66 (2009).

54. Xia, Z. et al. Conventional versus real-time quantitative PCR for rare species detection. Ecol. Evol. 8, 11799-11807 (2018).

55. Yang, T. B., Liu, J. \& Chen, J. Compared with conventional PCR assay, qPCR assay greatly improves the detection efficiency of predation. Ecol. Evol. 10, 7713-7722 (2020).

56. Mauvisseau, Q. et al. Influence of accuracy, repeatability and detection probability in the reliability of species-specific eDNA based approaches. Sci. Rep. 9, 1-10 (2019).

57. Smith, C. J. \& Osborn, A. M. Advantages and limitations of quantitative PCR (Q-PCR)-based approaches in microbial ecology. FEMS Microbiol. Ecol. 67, 6-20 (2009).

58. King, R. A., Read, D. S., Traugott, M. \& Symondson, W. O. C. Molecular analysis of predation: A review of best practice for DNAbased approaches. Mol. Ecol. 17, 947-963 (2008).

59. Burbank, L. P. \& Ortega, B. C. Novel amplification targets for rapid detection and differentiation of Xylella fastidiosa subspecies fastidiosa and multiplex in plant and insect tissues. J. Microbiol. Methods 155, 8-18 (2018).

60. Alberdi, A. et al. Promises and pitfalls of using high-throughput sequencing for diet analysis. Mol. Ecol. Resour. 19, 327-348 (2019).

61. Sow, A., Haran, J., Benoit, L., Galan, M. \& Brévault, T. DNA metabarcoding as a tool for disentangling food webs in agroecosystems. Insects 11, $294(2020)$.

62. Wood, S. A. et al. A comparison of droplet digital polymerase chain reaction (PCR), quantitative PCR and metabarcoding for species-specific detection in environmental DNA. Mol. Ecol. Resour. 19, 1407-1419 (2019).

63. Maslo, B. et al. Chirosurveillance: The use of native bats to detect invasive agricultural pests. PLoS ONE 12, e0173321 (2017).

64. Purcell, R. V. et al. Comparison of standard, quantitative and digital PCR in the detection of enterotoxigenic Bacteroides fragilis. Sci. Rep. 6, 1-8 (2016).

65. Behrens-Chapuis, S., Herder, F. \& Geiger, M. F. Adding DNA barcoding to stream monitoring protocols-What's the additional value and congruence between morphological and molecular identification approaches?. PLoS ONE 16(1), e0244598 (2021).

\section{Acknowledgements}

We thank all who collaborate in the acquisition of samples and specially to Joxerra Aihartza for its invaluable help and support during the investigation. We are also grateful to the Sequencing and Genotyping Unit-Genomic Facilities-SGIker (UPV/EHU/ERDF, EU) for the technical support provided. This project was funded by the Spanish Ministry of Economy and Competitiveness and the European Regional Development Fund (CGL-201569069P), as well as the Government of the Basque Country (IT754-13 and IT1163-19). The Basque Government Granted UB (PRE_2019_2_0186).

\section{Author contributions}

U.B., I.G. and designed the research. U.B., N.V. and A.C. conducted experiments. U.B. and C.I. participated in the sample collection. U.B. and A.B. designed molecular assays. U.G. and I.G. acquired funding. All authors read and approved the manuscript.

\section{Competing interests}

The authors declare no competing interests.

\section{Additional information}

Supplementary Information The online version contains supplementary material available at https://doi.org/ 10.1038/s41598-022-06195-7.

Correspondence and requests for materials should be addressed to U.B.

Reprints and permissions information is available at www.nature.com/reprints.

Publisher's note Springer Nature remains neutral with regard to jurisdictional claims in published maps and institutional affiliations. 
(c) (i) Open Access This article is licensed under a Creative Commons Attribution 4.0 International cc) License, which permits use, sharing, adaptation, distribution and reproduction in any medium or format, as long as you give appropriate credit to the original author(s) and the source, provide a link to the Creative Commons licence, and indicate if changes were made. The images or other third party material in this article are included in the article's Creative Commons licence, unless indicated otherwise in a credit line to the material. If material is not included in the article's Creative Commons licence and your intended use is not permitted by statutory regulation or exceeds the permitted use, you will need to obtain permission directly from the copyright holder. To view a copy of this licence, visit http://creativecommons.org/licenses/by/4.0/.

(C) The Author(s) 2022 